\title{
The Influence's Culture Work on the Work Effectiveness of Employees at the Communication and Informatics Agency Province of West Sumatera
}

\author{
Khaira Annisa ${ }^{a, 1, *}$ Aldri Frinaldi ${ }^{b, 2}$ \\ ${ }^{1,2}$ Public Administration, Universitas Negeri Padang, Indonesia \\ 1 khairaannisa6@ gmail.com, 2 aldri@ fis.unp.ac.id \\ * corresponding author
}

\section{ARTICLE INFO}

Article history

Received 2020-02-02

Revised 2020-05-05

Accepted 2020-06-22

Keywords

Work Culture, Work Effectiveness,

Employees, West Sumatera

\begin{abstract}
Communication and informatics office of west Sumatra make efforts to increase employees' working effectiveness in achieving working target. However, there are specific problems in working implementation. The problems are teamwork among the employees, working facilities is not supported, and lack of field specialization.

This research use descriptive quantitative method to address the aim to know the influence between independent variable (working culture) towards dependent variable (employees' working effectiveness). The population of this research is employee of Communication and informatics office of west Sumatra that is 47 employees. This research use total sampling which the total sample is equal to total population. The result of this research show significance effect partially and simultaneously between working culture towards employees' working effectiveness.
\end{abstract}

\section{INTRODUCTING}

Actualizing human resources who are ready to serve well is an important to achieve the goal of organization. Many ways have done by the organization to achieve maximum result. The employee's action is the main human resources reflect the achievement of the result.

The achievement of the goals an organization is seen from the effectiveness and efficiency of employees in carrying out the tasks that have been given. Zaini \& Agustian (2019) explain that accuracy of an employee in carrying out the task must be full of responsibility, be discipline at work, team work and achieve the goal that has been dealing with, that is effectiveness of employees at work. Effectiveness is also a benchmark in a job with the greatest possible result with prime quality and must be in accordance with guidelines that can provide satisfaction to everyone in the organization.

The employee's effectiveness in working must be main spotlight in public organization especially in Communication and Informatics Agency in doing tasks to achieve the goal. Fluency and satisfaction of employee is effected the achievement of goal, including successfulness of employee to optimize the achievement. The researcher find base on the interview that the problems of employee in Communication and informatics Agency are: Lack of coordination of each sector, lack of facilities and infrastructures which support the employee in doing the tasks especially in statistic sector.

In creating the convenience among employee Communication and Informatics Agency gives to employees the reward for best achiever and punishment for bad achiever who cannot achieve the target or who break the rules.

Base on the problems above the researcher has interest to do study in The Influence's Culture Work on the Work Effectiveness of Employees at the Communication and Informatics Agency Province of West Sumatera (Pengaruh Budaya Kerja terhadap Efektivitas Kerja Pegawai di Dinas Komunikasi dan Informatika Provinsi Sumatera Barat). the research of this study is to examine effect of the influence's culture work on the work effectiveness of employees at the communication and informatics agency province of west Sumatera. 


\section{LITERATURE}

\section{Work effectiveness}

Steers in Sutrisno (2011:123) states that effectiveness that is generally related to the objectives or organization, namely profit. Then about aspects of human resources that must be the primary focus, efforts in increasing effectiveness should always be started by examining how human behavior is crushed by work. Then Siagian (2002:171) in (Andriani, dkk ,2019) defines that effectivity is the target achievement of an organization that has been targeted on exactly time accordance of certain sources to do that activities. Futhermore, according to Yazid (2009:49) leader working effectiveness has to consider these criteria as follow:

1. Working quality including accuracy, ability and neatness

2. Working quantity including the amount of output, both routine output and extra output

3. Time accuracy, whether the job is in accordance with the predetermined standard time, faster or slower.

4. Target, which what has been done in accordance with the target.

Similar with that, Gibson and friends in Organization book the 8 edition which is translated in to Bahasa (1996) states that there are several things that impact the effectiveness in organization, such as: neighborhood, technology, strategy choices, process and culture.

Base on the definition above can be resume that Work effectiveness is anything that related to the target achievement an organization. The less employee's error the most effectiveness. Work effectiveness can be related to the utilization of generally sources (human, facility and infrastructure, etc.) in an organization to support the achievement.

In measure the work effectiveness Richard and M.Steers (1980:192) in (Yudhaningsih,2011) explain that there are many indicators in measure the work effectiveness; self-adjustment, work performance, and work satisfaction. ThenCampbell (in Putri, 2017) such as: awareness, efficiency, presence, work effort, motivation and satisfaction.

\section{Work Culture}

An organization can be created the best products or services when the organization has good work culture in achieve organization goals. In Kusdi (2011:110) states that culture in an organization role in provide cultural form in attachment of employee to organization, cultural form including: language symbol, narrative and activities that build the member characters and norms, and gives the meaning in lifestyle of employee.

In the management and entrepreneur magazine November- December edition (in Ndraha,2005) define work culture is the basic mental group or mental program that can be used to improve work efficiency and human cooperation possessed by a community group. Then Aldri Frinaldi (2017) states that Work culture us a positive and negative value perspective, then work way, mindset and behavior individual or group in a work. Same with that, Budi Pramata (Ndraha, 2005) explain that job culture parts become 2: work attitude and work behavior in work.

Base on the explanation above can conclude become work culture is values, mindset of group in an organization which becomes a role model for him in carrying out the work used to increase the effectiveness and efficiency of work so that the success of the organizational goals. Indicators in measuring work culture base on Aldri Frinaldi (2017) include: leadership, appearance, consciousness, communication, value and trust. Then Taliziduhu Ndraha (Cakra,2020) states that indicators of work culture are: habit, rules, etc.

Moreover, Taliziduhu Ndraha (Cakra, 2020) stated that indicator for measuring working culture as: habits, regulations, and values.

In addition, according to Budi Pramita (in TaliziduhuNdraha, 2005: 208) working culture indicators can be divided into two, as follow: 
a. Attitude towards work is a pleasure to work compared to other activities, such as relaxing, getting satisfaction from being busy with one's own work, or feeling forced to do something just for its survival.

b. Behaviors at work such as being diligent, dedicated, responsible, careful, thorough, careful, a strong willingness to learn about their duties and obligations, like helping fellow employees or vice versa.

In simply conceptual framework that researcher draw is:

\begin{tabular}{|c|c|}
\hline $\begin{array}{c}\text { Work Culture } \\
\text { (X) }\end{array}$ & $\begin{array}{l}\text { Work effectiveness } \\
\text { (Y) }\end{array}$ \\
\hline $\begin{array}{l}\text { measuring work culture } \\
\text { base on Aldri Frinaldi } \\
\text { (2017) } \\
\text { 1. Leadership } \\
\text { 2. Appearance } \\
\text { 3. Consciousness, } \\
\text { 4. Communication, } \\
\text { 5. Apreciation and } \\
\text { recognition } \\
\text { 6. value and trust. }\end{array}$ & $\begin{array}{l}\text { (1980:192) in } \\
\text { (Yudhaningsih, 2011) } \\
\text { 1. self-adjustment, } \\
\text { work } \\
\text { 2. performance, and } \\
\text { 3. work satisfaction }\end{array}$ \\
\hline
\end{tabular}

Image 1. Conceptual framework

Based on the description of the theoretical study and conceptual framework above, the research hypothesis is formulated as follows:

$\mathrm{H}_{1}$ :There is a significant influence between work culture on the work effectiveness of employees in the Communication and Information Office of West Sumatra Province

$\mathrm{H}_{0}$ :There is no significant influence between work culture on the work effectiveness of employees at the West Sumatra Communication and Informatics Office

\section{METHOD}

This research uses quantitative methods with a descriptive approach. The population in this study were 47 employees at the Communication and Informatics Office of West Sumatra Province. In this study, sampling using total sampling with the entire population as the research sample. Collecting data using a questionnaire distributed to respondents using a Likert scale measurement.

Then the validity of the research instrument was obtained from the validity test and reliability test with the help of the Statistical Product and Service Solution (SPSS) program version 25. To test the validity of the questions on the questionnaire can be seen from the Corrected Item-Total Correlation, with a validity limit of 0.361 .

Furthermore, the classical assumption test is in the form of normality test, linearity test, heteroscedasticity test, and autocorrelation test. After that the collected data is processed using a simple linear regression formula.

\section{RESULTS AND DISCUSSION}

\section{Research result}

The classic assumption test in regression research is the first step that must be taken in fulfilling the good regression requirements. The classical assumption tests carried out in this study are as follows: 


\section{Normality test}

Table 1. Normality Test Results

One-Sample Kolmogorov-Smirnov Test

\begin{tabular}{|ll|r|}
\hline $\mathrm{N}$ & & \multicolumn{1}{|c|}{ Unstandardized Residual } \\
Normal Parameters ${ }^{\mathrm{a}, \mathrm{b}}$ & Mean & 47 \\
& Std. Deviation & .0000000 \\
& Absolute & 2.66245214 \\
Most Extreme Differences & Positive & .135 \\
& Negative & .135 \\
Kolmogorov-Smirnov Z & & -.097 \\
Asymp. Sig. (2-tailed) & & .923 \\
\hline
\end{tabular}

a. Test distribution is Normal.

b. Calculated from data.

Source: 2020 Research Processed Data

Based on table 1 above, it is found that the Asymp. Sig (2-tailed) of 0.362>0.05, meaning that the residual value of this study is normally distributed. The normality test as one of the prerequisites for conducting the regression test has been fulfilled. In addition, the normality test can also be seen using the analyzed data graph. Data that is normally distributed will form a bell (bell shaped) as shown in the following figure:

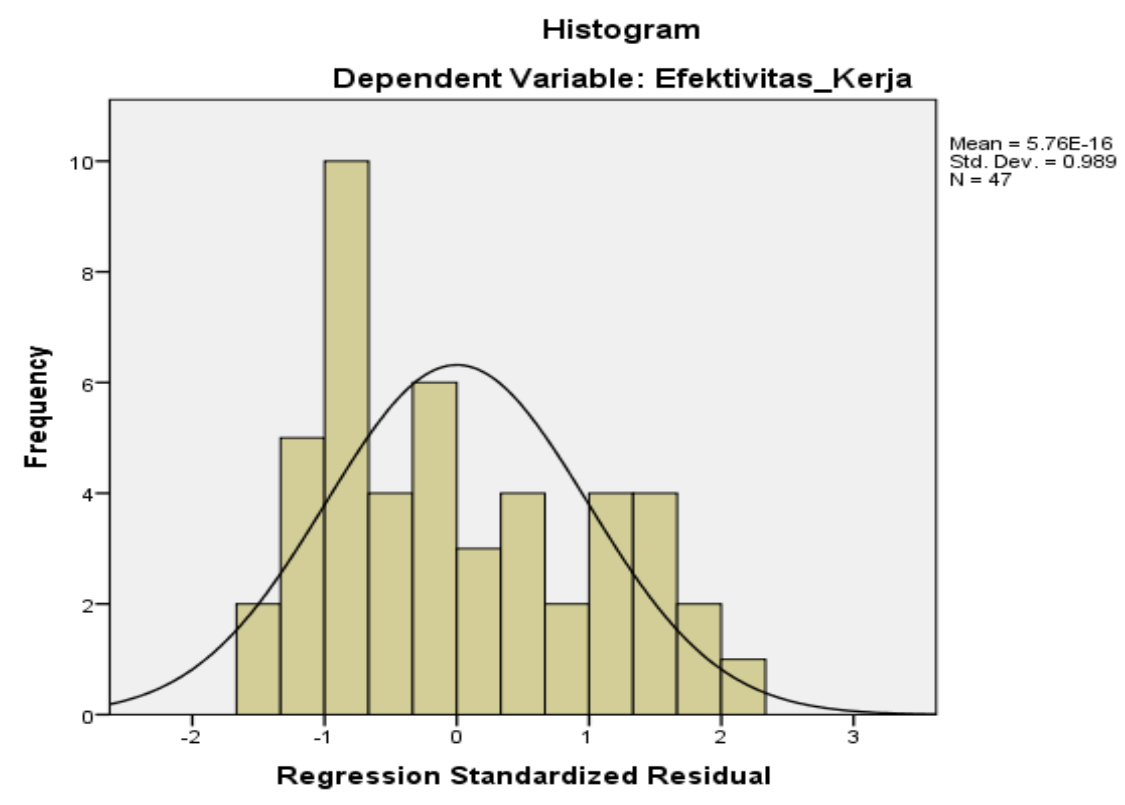

Image 2. Normality Test Results

Sources: 2020 Research Processed Data

Based on Figure 2 above, it is obtained the results of normality test data showing good data analysis and it can be said that the research data is normally distributed because it forms a normal curve.

\section{Linearity Test}

Table 2. Linearity Test Results ANOVA Table

\begin{tabular}{|c|c|c|c|c|c|c|c|}
\hline & & & $\begin{array}{l}\text { Sum of } \\
\text { Squares }\end{array}$ & df & $\begin{array}{l}\text { Mean } \\
\text { Square }\end{array}$ & F & Sig. \\
\hline \multirow{5}{*}{$\begin{array}{l}\text { Efektivitas Kerja * } \\
\text { Budaya Kerja }\end{array}$} & & (Combined) & 152.631 & 6 & 25.438 & 3.652 & .006 \\
\hline & Between & Linearity & 105.156 & 1 & 105.156 & 15.098 & .000 \\
\hline & Groups & Deviation from & 47.475 & 5 & 9.495 & 1.363 & .259 \\
\hline & Within G & & 278.603 & 40 & 6.965 & & \\
\hline & Total & & 431.234 & 46 & & & \\
\hline
\end{tabular}

Source : 2020 Research Processed Data 
Based on the test results in table 2 above, it is known that the significance value of linearity is 0.000 , because the significance of linearity is small from 0.05 , it can be concluded that work culture variables are influenced by work effectiveness. besides that, another way to do a linearity test is in the following figure:

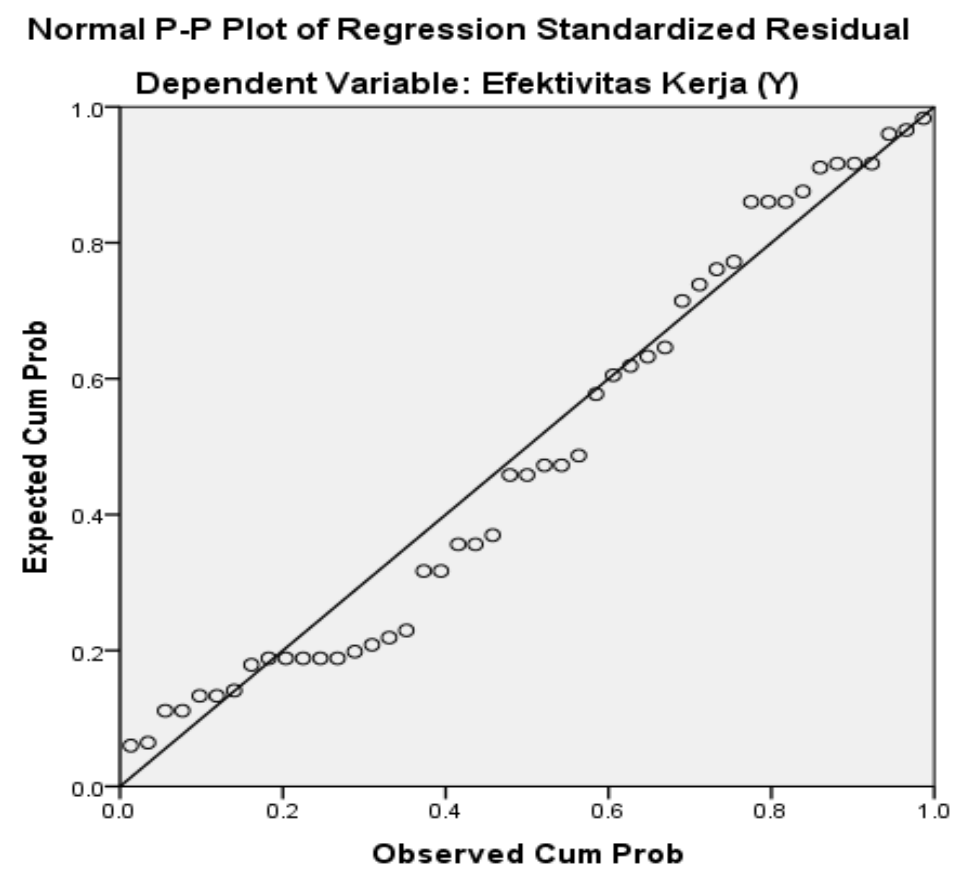

Figure 3 Normal Probability Plot Linearity Test Curve Source: 2020 Research Processed Data

Based on Figure 3 above, it can be seen that the points move and spread along a diagonal line or along the line and there is no extreme spread, which means that this regression model has met the normality assumption requirements of the data so that it is expected to be in accordance with the classical assumption of a regression.

\section{Heteroscedasticity Test}

Table 3. Heteroscedasticity Test Results

Coefficients $^{\mathbf{a}}$

\begin{tabular}{|c|c|c|c|c|c|c|}
\hline \multirow{2}{*}{\multicolumn{2}{|c|}{ Model }} & \multicolumn{2}{|c|}{ Unstandardized Coefficients } & \multirow{2}{*}{$\begin{array}{c}\begin{array}{c}\text { Standardized } \\
\text { Coefficients }\end{array} \\
\text { Beta }\end{array}$} & \multirow[t]{2}{*}{$\mathrm{t}$} & \multirow[t]{2}{*}{ Sig. } \\
\hline & & B & Std. Error & & & \\
\hline & (Constant) & 3.052 & 2.800 & & 1.090 & .282 \\
\hline & Budaya Kerja (X) & -.035 & .122 & -.042 & -.284 & .778 \\
\hline
\end{tabular}

a. Dependent Variable: Abs_RES

Source: 2020 Research Data Processed Results

From table 3 above, it can be concluded that there is no heteroscedasticity effect in this study, because each variable has a significance value above 0.05 .

\section{Autocorrelation Test}

Autocorrelation test in this study using the provisions of the Durbin Watson (DW) value.

Testing criteria that must be followed as follows:

1. If the DW value is below -2 it means there is positive autocorrelation

2. If the DW value is between -2 to +2 it means that there is no autocorrelation

3. If the DW value is above +2 , it means that there is negative autocorrelation

After the autocorrelation test was carried out in the study, the DW values were obtained as follows: 
Table 4. Autocorrelation Test Results

Model Summary ${ }^{\mathrm{b}}$

\begin{tabular}{|l|r|r|r|r|r|}
\hline $\begin{array}{l}\text { Mode } \\
1\end{array}$ & \multicolumn{1}{|c|}{$\mathrm{R}$} & R Square & $\begin{array}{c}\text { Adjusted R } \\
\text { Square }\end{array}$ & $\begin{array}{c}\text { Std. Error of } \\
\text { the Estimate }\end{array}$ & $\begin{array}{c}\text { Durbin- } \\
\text { Watson }\end{array}$ \\
\hline 1 & $.494^{\mathrm{a}}$ & .244 & .227 & 2.692 & 1.625 \\
\hline
\end{tabular}

a. Predictors: (Constant), Working culture

b. Dependent Variable: Working effectiveness

Source: 2020 Research Data Processed Results

From table 4.9 above, it can be seen that the Durbin Watson value is 1.625 , which means that this value is between -2 to +2 so it can be concluded that in this study there is no autocorrelation problem.

\section{Regression Test}

Table 5. Simple Linear Regression Test Coefficients $^{\mathrm{a}}$

\begin{tabular}{|rl|r|r|r|r|r|}
\hline \multicolumn{2}{|l|}{ Model } & \multicolumn{2}{|c|}{ Unstandardized Coefficients } & \multicolumn{1}{c|}{$\begin{array}{c}\text { Standardized } \\
\text { Coefficients }\end{array}$} & \multirow{2}{*}{ Sig. } \\
\cline { 3 - 7 } & & \multicolumn{2}{|c|}{$\mathrm{B}$} & Std. Error & Beta & \\
\hline \multirow{2}{*}{1} & (Constant) & 19.404 & 5.454 & & 3.558 & .001 \\
& Budaya Kerja & .904 & .237 & .494 & 3.809 & .000 \\
\hline
\end{tabular}

a. Dependent Variable: Efektivitas Kerja

Source: 2020 Research Data Processed Results

From table 4 above it can be found that the significance value is 0.000 because the significance value is $<0.05$, it is concluded that there is a significant influence on the Work Culture variable $(\mathrm{X})$ on work effectiveness (Y). Thus it can be stated that the hypothesis Ha is accepted, that is, there is a significant influence between Work Culture on Work Effectiveness in the Communication and Informatics Office of West Sumatra Province. These results indicate that there is an influence given by work culture variables on work effectiveness with a consistent value of 19,404. Then the regression coefficient is positive 0.904 , so it can be said that work culture (X) has a positive effect on employee work effectiveness (Y).

Table 6. The Effect of Variable X on Y

Model Summary ${ }^{b}$

\begin{tabular}{|l|r|r|r|r|r|}
\hline Model & \multicolumn{1}{|c|}{$\mathrm{R}$} & R Square & \multicolumn{1}{c|}{$\begin{array}{c}\text { Adjusted R } \\
\text { Square }\end{array}$} & $\begin{array}{c}\text { Std. Error of the } \\
\text { Estimate }\end{array}$ & Durbin-Watson \\
\hline 1 & $.494^{\mathrm{a}}$ & .244 & .227 & 2.692 & 1.625 \\
\hline
\end{tabular}

a. Predictors: (Constant), Budaya Kerja

b. Dependent Variable: Efektivitas Kerja

Source: 2020 Research Data Processed Results

From the table 4.26 above, it can be seen that the $\mathrm{R}$ Square value is 0.244 . This value means that the influence of work culture (X) on work effectiveness (Y) is $24.4 \%$, while $75.6 \%$ of work effectiveness is influenced by other variables that are not studied.

\section{DISCUSSION}

Based on the results of the hypothesis, it was found that the work culture variable partially had a significant influence on the work effectiveness variable. This is evidenced from the results of data processing using SPSS 25 software. That the significance value of the Work Culture variable on work effectiveness was found to be $0.000>0.05$. Based on these results it can be understood that the work culture variable has a significant influence.

The amount of influence that the work culture variable has on the work effectiveness of employees is $24.4 \%$. The other $75.6 \%$ are influenced by other variables not examined.

Work culture as a visible or invisible basis in a person, seen from the perspective of values and beliefs, understanding of how to work, norms, patterns of thought and behavior of each person or group of people who can help achieve organizational goals when accompanied by good leadership healthy communication, awareness of time, and a fair reward and punishment system (Aldri Frinaldi, 2017) 
The limitation of this study is that this study only focuses on the effectiveness of work at the West Sumatra Diskominfo. There are still many research variables that can be researched and developed such as, service quality, work productivity, work environment and employee happiness at work.

\section{Suggestion}

1. Improve coordination among employees as a form of effectiveness in carrying out workers so that they can achieve predetermined targets

2. Increasing the quality and quantity of facilities and infrastructure to support employees in working effectively

3. Adding and increasing field specialization so that targets can be achieved as expected

\section{REFERENCES}

Aldri Frinaldi.2017 The influence of Drive Work Culture and Service Quality on Citizen Satisfaction with Mass Transportasion at Sout Pesisir Region West Sumatra, Indonesia. Proceeding Advances in Social Science, Education and Humanities Research. Volume 84; pp.doi: 10.2991 / iconeg16.2017: 101

Aldri Frinaldi.2014. The Influence of Civil Servants Work Culture on Public Services in the Payakumbuh Civil and Population Registry Office. Humanus, Vol. XIII No.2 Th. 2014

Endra, F. 2017. Introduction to Research Methodology (Practical Statistics). Sidoarjo: Zifatama Jawara.

Kusdi.2011. Organizational Culture: Theory, Research, and Practice. Jakarta: Four Salemba.

Ndraha, T.2005. Organizational Culture Theory. Jakarta: PT RINEKA CIPTA

Sutrisno, edy.2011. Organizational culture. Kencana: Surabaya

Yudhaningsih, R.2011. Increasing Work Effectiveness through Commitment, Change and Organizational Culture. Variety of Humaninora Development Journal Vol. 11 No.1, 40-50. 